\title{
The Dismantling of Family Farming Policies in Brazil and Argentina
}

Eric Sabourin, Clara Craviotti and Carolina Milhorance

\section{(2) OpenEdition \\ 1 Journals}

Electronic version

URL: https://journals.openedition.org/irpp/799

DOI: 10.4000/irpp.799

ISSN: 2706-6274

Publisher

International Public Policy Association

\section{Printed version}

Date of publication: 27 April 2020

Number of pages: 45-67

ISSN: 2679-3873

\section{Electronic reference}

Eric Sabourin, Clara Craviotti and Carolina Milhorance, "The Dismantling of Family Farming Policies in Brazil and Argentina", International Review of Public Policy [Online], 2:1 | 2020, Online since 01 April 2020, connection on 21 September 2021. URL: http://journals.openedition.org/irpp/799 ; DOI: https:// doi.org/10.4000/irpp.799

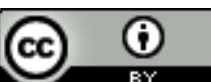

International Review of Public Policy is licensed under a Creative Commons Attribution 4.0 International. 


\section{The Dismantling of Family Farming Policies in Brazil and Argentina}

\section{Eric Sabourin}

Socio-anthropologist at CIRAD, UMR ART-Dev, MUSE University, Montpellier, France and visiting professor at the Center for Sustainable Development-University of Brasilia

\section{Clara Craviotti}

Sociologist, research fellow at CESOT, Faculty of Economic Sciences, University of Buenos Aires; National Council of Scientific and Technical Research (CONICET).

\section{Carolina Milhorance}

Research fellow at the Center for Sustainable Development - University of Brasilia. Her research currently focuses on topics such as policy integration and the strategies of adaptation to climate change, policy networks in the policy process, south-south cooperation and policy transfer.

\section{Abstract}

This article examines the recent processes of dismantling public policies oriented to promote or regulate family farming in Latin America. It addresses two main questions: How and why were these policies dismantled? Drawing on Bauer et al.'s (2012) analytical framework, the article examines the modalities and stages of the process of dismantling family farming policy instruments in Brazil and Argentina. Likewise, it analyzes the process's causes by delving into structural, contextual and institutional factors. It adopts this framework, originally developed for social policies in Europe, to analyze rural policies in Latin America. From a theoretical point of view, the study suggests the importance of analyzing the resilience of policies and the mechanisms and strategies of resistance to governmental shifts as these affect the degree and direction that the process of dismantling may take.

\section{Keywords}

family farming, public policies, policy dismantling, Latin America, Brazil, Argentina 


\section{Introduction}

The first decade of the $21^{\text {st }}$ century was marked by the consolidation of specific family farming policies in several Latin American countries. These policies combine a set of policy instruments targeted at a specific segment of farmers, those whose production units are associated with five characteristics/criteria: limited area; predominance of family labor; family management; gross income primarily from agricultural production; and residence on or near the farm (Sabourin, Samper, Sotomayor, 2015). Family farming-specific policies generally include three types of instruments (e.g., credit, technical assistance and organizational support), forming policy portfolios (Howlett \& del Rio, 2015).

The development of these policies in Latin America resulted from coalitions involving social movements and public actors, which benefited from the election of left-wing governments and seized windows of opportunity favorable to family farming groups (Sabourin, Samper, \& Sotomayor, 2015). However, since the early 2010s, these coalitions have lost space, resources, political weight and legitimacy, which has led to a progressive (and sometimes radical) dismantling of family farming policy instruments (Mattei, 2018, Nierdele et al., 2019; Nogueira, Urcola, \& Lattuada, 2017). While public policy studies have commonly addressed the assessment and explanation of different degrees of policy change, less attention was paid to the directions of change. Policy dismantling refers to a specific direction of change in which the patterns of "decrease" (or even reversal) of existing policy arrangements are taken into account. Comparative studies of this process have shown that the politics of dismantling varies significantly across different policy fields (Bauer \& Knill, 2012).

This article examines the processes of dismantling public policies oriented to promote or regulate family farming in Latin America. It addresses two main questions: How and why were these policies dismantled? Drawing on Bauer et al.'s (2012) analytical framework, the article examines the modalities and stages of the process of dismantling these policy instruments in Brazil and Argentina. Likewise, it discusses the causes of this process by delving into structural, contextual and institutional factors. It adds to the current literature by adapting the framework to a policy field and region that has received hardly any attention and by further elaborating the causes and processes of dismantling. It also provides insights into the resilience of these policies and into the mechanisms of resistance to short-term political pressures and governmental shifts.

This article argues that, in both countries, family farming policies carry a specific meaning related to struggles and agreements with historically dominant coalitions, which impacts on perceptions of the costs and benefits of dismantling. Moreover, both Brazil and Argentina face challenges in terms of institutional fragmentation, which restrains their systems of checks and balances in the assuring of basic rights, enabling power imbalance towards the executive branch of the government. Finally, it stresses that dismantling starts with discreet strategies before it reaches more active and disclosed forms. Brazil and Argentina were chosen as case studies as the agricultural sector has major importance in both countries' economies and politics and family farming groups are predominant in the agrarian structure of both countries, acquiring major political resources over the past decade, thereby reversing a previous situation of marginalization.

The first section presents the analytical framework of the study. The second section identifies policy instruments that have targeted family farms across Latin America and have led to their consolidation over time. The third section discusses the modalities and causes of policy dismantling in Brazil and Argentina. And, finally, the fourth section provides some potential responses to change and a possible future research agenda. 


\section{Analytical framework for policy dismantling}

\subsection{Theoretical background}

Despite increasing accounts of policy dismantling and rupture processes, these issues have not been systematically addressed by policy research (Jordan, Bauer, \& Green-Pedersen, 2013). Indeed, welfare-state retrenchment and the weakening of social policies have been addressed by institutionalist scholars (Pierson, 1994). Likewise, notions of rupture and critical moments have been mobilized by the neo-institutional economy, arguing the path dependence of policies (Mahoney, 2001). Finally, Rosanvallon (2014) and Levitsky and Ziblatt (2018) analyzed the regression of democracy and the generalization of neoliberal policies and new capitalist evolutions in Europe and the United States.

On the other hand, Howlett (2019) discusses means for improving the resilience and robustness of policies over time or, in other words, mechanisms for preventing policy dismantling. Resilience is the ability to adapt to major internal/external perturbations, while robustness refers to the ability to maintain the same performance in the face of a variety of contexts. According to Howlett, achieving both requires duplicating some resources and adding procedural policy tools (for monitoring and revising policies) in order to deal with unforeseen events and to "patch" policies over time. Nevertheless, while it is plausible that more institutional constraints and "lock-in" tools generally reduce chances for direct dismantling (and vice versa), this does not mean that, in such contexts, policy dismantling is not feasible (Jordan et al., 2013). The resilience of a given policy is therefore an important issue to analyze in the context of governmental shifts.

Rather than focus on the occurrence or non-occurrence of dismantling, it is crucial to analyze how, and to what extent, dismantling processes occur. However, most of these studies fail both to identify empirically the main causes and patterns of change and to provide an analytical framework for policy dismantling and comparative analyses (Jordan et al., 2013). Bauer, Jordan, Green-Pedersen and Héritier (2012) address this gap by developing a comprehensive framework for analyzing policy dismantling mechanisms, causes and outputs. Policy dismantling is thought of as a direction of policy change, implying the "reduction", "decrease", "diminution" - even reversal — of existing policy arrangements. These authors are concerned with two specific and interrelated sets of questions: first, under which conditions do political actors engage in policy dismantling? And second, given other actors' preferences, institutional constraints and opportunities, and specific situational factors, which strategies do they choose? Both questions are relevant to the case studies presented in this article and both provide analytical elements for answering the question of why and how family farming policies in Brazil and Argentina have been recently dismantled. These will be further developed below.

\section{Structural, institutional and situational factors}

The factors leading to policy change through dismantling may be separated into three different types: i) external factors and prevailing macro conditions, such as the stability of the financial system, technological change, the spread of certain ideas of reform and unforeseen elections; ii) situational factors, which are primarily background issues; and iii) institutional constraints and opportunities, particularly those related to opportunity structures comprising the features of the political system (the polity). Depending on the specific combination of factors affecting the preferences of political actors and their capability to pursue policy dismantling, distinct strategies may be chosen (Bauer et al. 2012).

The first set of factors refers to socio-political or economic changes or events, including but not limited to major economic shocks, supranational policy pressure, governmental shift and change in policy paradigms. These factors are characterized by the fact that they are beyond 
the direct influence of policy actors and can shift the balance of power within the policy field, thereby supporting or undermining policy dismantling (Gürtler et al., 2019). The second group mainly relates to the political economy of the specific policy field, including the structural features of the sector, the configuration of actors and their interests and political power. According to Gürtler et al (2019), these factors also include the specific patterns of policy design, which shape the distribution of costs and benefits across those affected by a policy. Regarding the design of policy portfolios, the notion of resilience may add to the analytical framework. The notion refers to the ability to deal with opposition and conflict that may emerge over the medium-to-long term (Howlett, 2019). The design of "lock-in" tools that can reduce the changes for direct dismantling is considered here.

This point aligns with the third set of factors, which refers to the institutional constraints specific to each political system. According to Bauer et al. 2012, the electoral system, the party system and the strength of veto players (such as constitutional courts), among other factors, affect if, and to what extent, the government expects to be able to realize its dismantling objectives. Moreover, actors' perceptions of dismantling may be affected by election cycles and by the partisan positions of policymakers, which are ultimately related to the varying composition of governments and legislatures. An additional explanation for policy dismantling is the possibility of shifting the blame to subnational, supranational, or international actors and structures. Finally, the main factor refers to the extent to which the costs and benefits of dismantling are perceived to be dispersed or concentrated across affected actors. This perception is influenced by the policy features and the organizational and institutional structures characterizing the political system.

According to these arguments, dismantling policies that are perceived to have concentrated costs and diffused benefits (such as environmental policies) may be rewarding for some political actors, depending on the strength of the interest groups bearing the costs (for instance, well-organized economic groups opposed to environmental regulation groups). Meanwhile, interventions perceived to have diffused costs and concentrated benefits, such as social policies, are commonly led by politicians' blame-avoidance. This pattern is aligned with much of the welfare-state retrenchment literature; for instance, in the context of economic austerity, when politicians are "forced" to withdraw public funds from vulnerable beneficiaries. Note that these costs and benefits distributions reflect political actors' perceptions and are not an objective indicator.

Family farming policies comprise instruments of social participation and protection, productive inclusion and protection of minorities and are therefore theoretically comparable to the social policies type. However, as discussed in Sections 2 and 3, the distribution of the costs and benefits of dismantling is not straightforward in this case.

\section{Dismantling processes}

Regarding policy-dismantling stages and modalities, Bauer et al. (2012) identify four main approaches that differ according to the extent to which the process is consciously undertaken, as well as the extent to which political actors wish to hide or reveal their activities. First, dismantling by default relies on de facto retrenchment through budget allocations with low visibility and the absence of any decision attracting political attention. Second, dismantling by arena shifting refers to an actual decision to move a policy to a different arena such as another government level (i.e., decentralization), weak agencies, or another sector where the policy may receive lower priority. Water privatization in Europe would be an example of exempting public authorities from the responsibility of implementation.

Third, dismantling by symbolic action consists of ensuring that any dismantling intention is clearly and directly attributed to political decision-makers as it may be important to many ac- 
tors; therefore, political declarations do not necessarily lead to outputs but remain symbolic. This type of strategy may be the result of high institutional constraints, or of the heterogeneity of political actors' preferences. Finally, the most apparent strategy is active dismantling, which displays high visibility with a strong preference to dismantle. In this case, dismantling might be rewarding for political actors as a result of incisive demands or ideological positions. This movement may entail dismantling in one area along with expansion in others.

The theoretical framework presented above was predominantly applied to cases in Europe and the United States. The present study draws on this framework; however, it provides an original example by turning to Latin America. It highlights some of the particularities of these countries, namely the politicization of rural social (and productive inclusion) policies, resulting from the historical conflict with economic sectors and the institutional distinctions of their policy systems. Note that the comparative lens between Brazil and Argentina is particularly interesting from an empirical point of view. First, as mentioned earlier, the agricultural sector has a major importance in both countries' economies and politics. Second, family farming groups, which are the most relevant sector in quantitative terms and whose production is strategic for domestic consumption, have acquired major political resources over the past decade. Third, both Brazil and Argentina adopted targeted-family farming policy instruments in the early 2000s and began the dismantling processes in 2015-2016. Fourth, these two countries engaged, in the late 2000s, in an effort to promote the regional diffusion of these policy instruments. Finally, despite the similar trajectories of development, diffusion and the early steps in dismantling family farming policies in the two countries, the causes and late evolution of dismantling are different in each context. In Argentina the process started after general elections and an overt change in the government's political and economic orientation, while in Brazil it has been part of a major crisis of the political system. The Figure 1 summarizes the analytical framework.

Figure 1: Policy dismantling framework

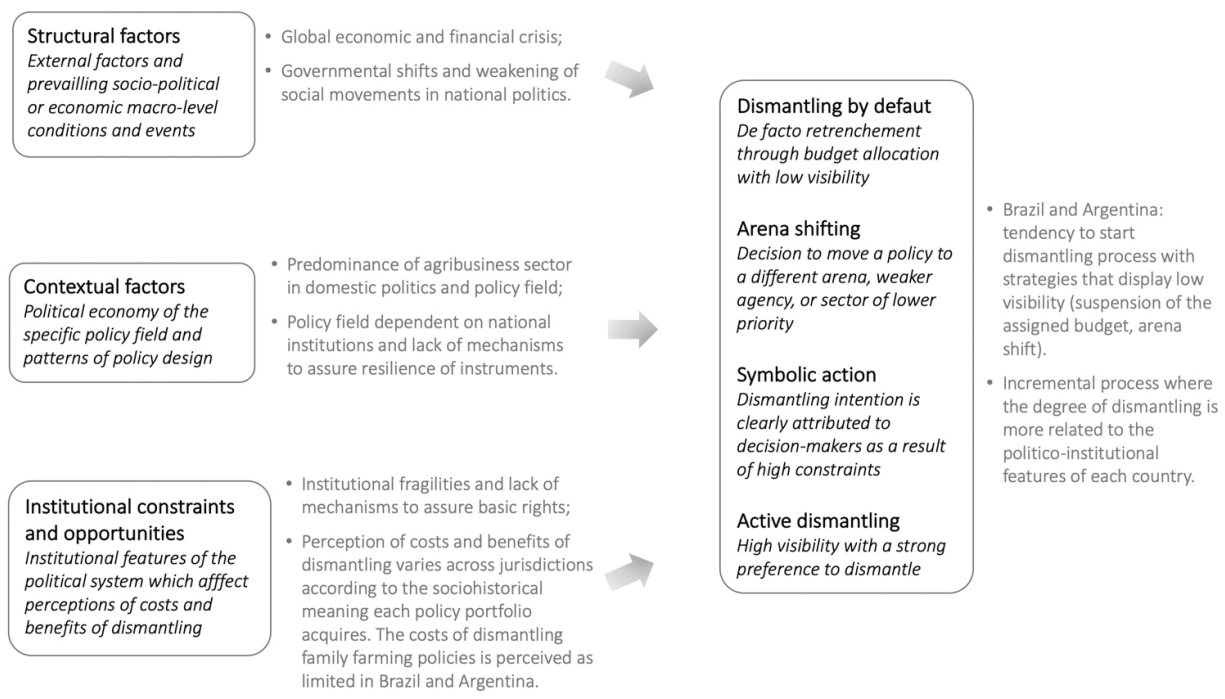




\subsection{Data collection}

The empirical data of this article was mainly provided by three collective studies carried out in various countries by the Research Network "Public Policies and Rural Development in Latin America" (PP-AL Network) between 2013 and 2018. The first study adopted a common framework to analyze the development of family farming policies in eleven countries. The second study, held in 2016, detailed the constraints of these policies, particularly regarding instruments of promotion of organic farming and agroecology (Sabourin, Le Coq, et al., 2018). Between 2016 and 2018, the third study analyzed the influence of Brazil and Argentina in the regional diffusion and transfer of family farming policy instruments (Sabourin, Grisa, et al., 2020; Sabourin, Grisa, and Lopez, 2018, Sabourin and Grisa, 2018). A brief update was conducted in 2018 (Grisa, Sabourin, \& Le Coq, 2018) and in 2019, after the election of far-right groups to the presidency of Brazil and the expansion of the economic crisis in Argentina.

The aforementioned studies used process-tracing methodologies, based on semi-structured interviews with policymakers and social actors and on official documents. For the purpose of this article, additional primary information was collected specifically for the cases of Brazil and Argentina and a qualitative cross-case analysis, focused on the causes and processes of the dismantling of family farming policy instruments, was held. By shedding light on the trajectories of the development and dismantling of these policies, their specific content, main actors and coalitions, the article shows that the causal mechanisms and processes proposed by Bauer et al. are consistent with the evidence from the case studies and further elaborates the framework to facilitate future in-depth and regionally based analyses.

\section{Emergence and consolidation of family farming policies in Latin America}

This section identifies a variety of policy instruments that have targeted family farming across Latin America over time, including — but not limited to - the distinctive policies in Brazil and Argentina. The emergence of these policies has been distinct according to the country, in terms of time period, supporting coalitions and windows of opportunity (Adib \& Almada, 2017). Most of the policies reveal the role of rural social movements which, at certain times, managed to form coalitions able to influence public decisions.

The emergence of family farming policies in Latin America can be divided into three broad generations (Sabourin et al., 2015). The first generation (1950s-1980s) was guided by the goals of promoting access to land and developing the economic and technical capacities of family farmers and included the promotion of land reforms and, to varying degrees, agricultural credit and technical assistance. Most of these policies were either interrupted or stunted by periods of military dictatorship. Alternatively, in countries like Brazil, Uruguay, Peru and Bolivia, these goals were converted to policies of colonization of public lands on the agricultural frontiers of the Pampas or Amazon regions. In these countries, land-access initiatives were supported by international organizations (such as the Food and Agriculture Organization-FAO and the World Bank) and accepted by dictatorship governments as they were intended to prevent "communists" from advancing into the countryside.

The second generation (1996-2000s in Brazil, early 2000s in other countries) corresponds with a period of diversification of instruments targeting family farmers. In general terms, a common portfolio for supporting family farming comprised: i) registration mechanisms to define beneficiaries (sometimes legally binding); ii) agricultural credit specifically targeted to family 
farmers; and iii) capacity-building programs (basically, rural extension and support for local organizations). These policies were commonly supported by progressive left-wing governments that invested increasing amounts of public funds in family farming support (Alves \& Rocha, 2010). Paradoxically, the main difference between countries resided in the definition of the "family farming" category, which varied according to the specificity of the land structure, the history of the peasantry and the type of social and political support that the national government sought to preserve (Sabourin et al., 2015).

It is worth noting that public support for family farming received low opposition during the 2000 s as the potential competitors for the public budget - the agribusiness sector - benefited from the expansion of commodities' international markets during this decade. Moreover, several programs relied on the integration of a productive family farming elite with commodity value chains, a model that received the endorsement of liberal governments. For instance, the National Program to Strengthen Family Agriculture in Brazil (Pronaf) provided support by issuing credit to family producers who were already inserted into commodity agri-food chains for their technological modernization (Aquino \& Schneider, 2010).

The third generation (from 2005) comprises policy instruments addressing global development challenges, such as food and nutrition security, adaptation to climate change, sustainable or territorial development and global poverty alleviation. These instruments are not explicitly focused on the family farming category; however, they have been recognized as being promising for the empowerment of family farmers through the implementation of consultative bodies and compensation contracts, such as payments for environmental services (Ezzine, Le Coq, 2017). They are particularly relevant for diversifying and completing family farming policy portfolios and for addressing adapted support to specific segments: the rural poor; the native, peasants', or fishers' communities; women and youth, etc. (Sabourin \& Grisa, 2019).

Table 1 summarizes some of these policy instruments established in Brazil and Argentina. Their evolution, as well as their appropriation and advocacy by distinct political and economic groups, will, over time, affect the constellation of the costs and benefits of reinforcing or dismantling them, which is discussed in the following sections. 
Table 1: Main policy instruments affecting family farming in Brazil and Argentina, by field of intervention

\begin{tabular}{|c|c|c|}
\hline & Brazil & Argentina \\
\hline $\begin{array}{l}\text { 1- Generalist } \\
\text { agricultural policy } \\
\text { instruments }\end{array}$ & $\begin{array}{l}\text { - Agrarian reform and land } \\
\text { colonization by the Ministry of } \\
\text { Agriculture, 1962-1998. }\end{array}$ & $\begin{array}{l}\text { - Generalist agriculture policy } \\
\text { shaped for business farming by } \\
\text { Secretary of Agriculture (mid-1980, } \\
\text { replaced by MINAGRI in 2008). }\end{array}$ \\
\hline \multirow[t]{3}{*}{$\begin{array}{l}\text { 2- Specific } \\
\text { targeted family } \\
\text { farming policy } \\
\text { instruments }\end{array}$} & $\begin{array}{l}\text { - Establishment of the National } \\
\text { Program Supporting Family } \\
\text { Farming (Pronaf), including } \\
\text { agricultural credit specifically } \\
\text { targeted at family farming and a } \\
\text { family farming national register, } \\
\text { 1995; }\end{array}$ & $\begin{array}{l}\text { - Establishment of distinct } \\
\text { programs: Minifundio (Small } \\
\text { Units), 1987; PPNEA (Program for } \\
\text { small producers of the northeast); } \\
\text { Cambio Rural (Rural Change), } \\
\text { Programa Social Agropecuario } \\
\text { (Agriculture Social Program), 1993; }\end{array}$ \\
\hline & $\begin{array}{l}\text { - Creation of the Ministry of } \\
\text { Agrarian Development, focused on } \\
\text { family farming and land policies, } \\
\text { 1999; }\end{array}$ & $\begin{array}{l}\text { - PROINDER (Rural Initiatives } \\
\text { program), 1998; }\end{array}$ \\
\hline & $\begin{array}{l}\text { - Technical assistance and rural } \\
\text { extension policy, } 2004 .\end{array}$ & $\begin{array}{l}\text { - National Family Farming Register, } \\
\text { 2007; } \\
\text { - Secretariat of Rural Development } \\
\text { and Family Farming, 2009; } \\
\text { - Social Agricultural Monotribute, } \\
2009 .\end{array}$ \\
\hline \multirow[t]{2}{*}{$\begin{array}{l}\text { 3- Sustainable } \\
\text { development and } \\
\text { rural-territories } \\
\text { policy instru- } \\
\text { ments }\end{array}$} & $\begin{array}{l}\text { - Support for the development of } \\
\text { rural territories (PRONAT and } \\
\text { Citizenship Territories Program), } \\
\text { 2004-2008; }\end{array}$ & $\begin{array}{l}\text { - National Rural Sustainable } \\
\text { Development Program } \\
\text { (PROFEDER), 2011; }\end{array}$ \\
\hline & $\begin{array}{l}\text { - Technical assistance and financial } \\
\text { support for the development of } \\
\text { agroecology and organic farming } \\
\text { (PNAPO), } 2012 \text {. }\end{array}$ & - PROINDER, second stage, 2009. \\
\hline $\begin{array}{l}\text { 4- Food security } \\
\text { and reduction of } \\
\text { rural poverty poli- } \\
\text { cy instruments }\end{array}$ & $\begin{array}{l}\text { - Social protection combined with } \\
\text { public food purchases (Zero Hun- } \\
\text { ger Program, National Food and } \\
\text { Nutritional Security Council, Food } \\
\text { Acquisition Program, School } \\
\text { Feeding Program), 2003, } 2009 .\end{array}$ & $\begin{array}{l}\text { - Program of Provision of Running } \\
\text { Water, Social Help and Basic } \\
\text { Sanitation (PROPASA), 1999; } \\
\text { - National Food Security Plan, } \\
2003 .\end{array}$ \\
\hline
\end{tabular}




\section{Crisis and dismantling of family farming policies in Brazil and Argentina}

\subsection{Strategies and stages}

In Brazil and Argentina, a common feature of the policy dismantling process is the orientation of its early steps by diffuse and unnoticeable strategies. Even though, in both countries, the dismantling process subsequently reached an active and "credit claimer" approach, the process began with dispersed institutional changes, which is consistent with Bauer et al.'s claims regarding the expected degree of resistance to dismantling (Bauer et al., 2012). This observation also aligns with recent literature on the weakening of democratic systems worldwide. Levitsky and Ziblat (2018) describe how governmental efforts to subvert modern democracies are approved by legislative power and by the courts. There is no coup d'état or turning point: change is almost invisible. Keeping in mind the due proportion of association between democratic systems and specific policies, the argument refers to the initial invisibility of the dismantling process for policies which are committed to basic rights.

This section discusses the sequencing of Bauer et al.'s categories of dismantling. Most dismantling processes begin with discreet strategies, which are usually justified by economic austerity in the face of a budget crisis. In the case of family farming, however, the dismantling process reached an active approach using undemocratic strategies based on the denial of the legitimacy - and even criminalization - of the political opponents. This has been particularly apparent in the case of Brazil where the dismantling process followed major changes in the politicoinstitutional system.

\section{Brazil: from default to active dismantling}

The first signs of the dismantling of family farming policy instruments in Brazil came during the second mandate of Dilma Rousseff (2014-2016). Her administration made ambiguous decisions about land reform, as it prioritized the titling of already allocated land instead of allocating land to new beneficiaries (Sabourin, 2018). There was also a reduction of funds, attempts to merge the Ministry of Agrarian Development (MDA) and the Ministry of Social Development (MDS), and paralysis of the new National Agency for Technical Assistance and Rural Extension (ANATER) (Niederle et al., 2019). These actions resulted from the weakening of parliamentary support for the government in the congress, the prioritization of support for agribusiness ${ }^{1}$ in the context of economic recession, and a decrease in public resources for these policies. Drawing on Bauer et al.'s categories, this was the beginning of a "dismantling by default", which relates to the diminishing of financial or political resources. This kind of strategy can, in principle, bypass political opposition for a long time, but certainly not forever (Bauer et al., 2012).

Other important signs of dismantling included lawsuits against the rural movements, including family farmer cooperatives. For example, in 2014, the conservative sectors in the states of Paraná and São Paulo obtained a series of administrative-zeal measures from the Public Prosecutor's Office and the Brazilian Federal Court of Audit that concealed a mechanism for criminalizing movements; this was based on excessive control and a literal interpretation of the contracts for public purchases of food coming from family farmers (Hentz and Hespanhol, 2018). Thus, by the end of the first Rousseff mandate, several cooperatives and associations that managed the Family Farming Food Acquisition Program (PAA) contracts had their leaders convicted and imprisoned for having delivered boxes of lettuce in place of cabbages for schools' canteen supplies - they were finally absolved in 2017. Also, the director of the National Supply Company (CONAB) of the Ministry of Agriculture, Livestock and Supply (MAPA), responsible

11 - The Minister of Agriculture was the former President of Brazil's Confederation of Agribusiness, the main representation body for large agricultural companies. 
for the PAA, was fired.

Rousseff was impeached by congress in 2016, a process led by a right-wing coalition particularly aligned with conservative and ultraliberal ideas. Michel Temer took office in October 2016 and, since then, the country has witnessed the active and rapid dismantling of family farming policies. The MDA was dissolved and its programs were transferred to the Ministry of Social and Agrarian Development (MDSA), in accordance with the proposal of researchers who affirmed that family farming should be assisted by social rather than productive policies (Alves \& Rocha, 2010). According to this argument, the family farming category included too many types of non-productive segments (indigenous communities, traditional peasant people, small fishermen, etc); hence, productive support should be limited to farmers integrated into the agri-food chains (Alves et al, 2010; Navarro \& Pedroso, 2011).

Subsequently, as a result of the inability of MDSA civil servants to manage agricultural programs on the one hand and, on the other hand, the reactions of social movements, the former MDA secretariats were brought together in a single entity, the Special Secretariat for Family Agriculture and Agrarian Development (SEAD). Pronaf's credit lines had been maintained, but without technical assistance, and it ended up running very slowly due to the suspension of the assigned budget. There was a call by interest groups supporting this government that these credit lines should further benefit middle-income and agribusiness farmers. The graphs of the evolution of the budgets for family farming instruments and for land-reform actions clearly illustrate the decrease in resources (Figure 2). On the other hand, instruments of support for the development of rural territories became completely paralyzed and the land-reform program that had just been revised was transferred to the Civil House as a means of centralizing the control of its evolution. Thus, the process initially driven by a strategy of arena-shifting was later replaced by an active dismantling.

Figure 2: Financial resources allocated to family farming and land reform policy instruments between 2015 and 2018, BRL million

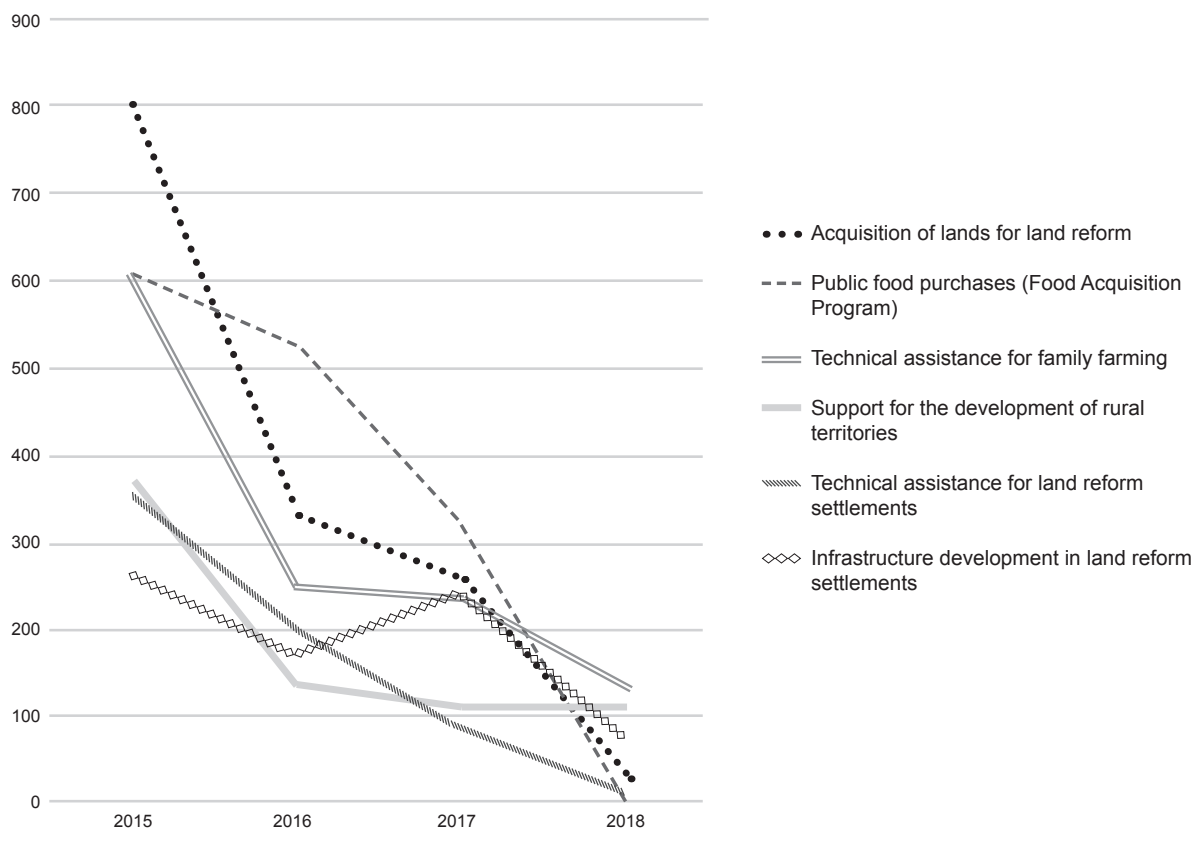

Source: Niederle et al., 2019 
After the 2018 Bolsonaro election, the dismantling process was expanded to additional sectors, including environmental and education policies, and pursued an even more radical and open strategy. The SEAD was renamed Secretariat of Family Farming and Cooperativism and subordinated to the Ministry of Agriculture (Decree 9667/2019), the institution historically identified with the interests of agribusiness sectors and recognized as participating in political tensions with the former MDA. Furthermore, most of the funds for family farming remained frozen by austerity measures and the councils for the design and monitoring of these policies were extinguished by presidential decree, particularly the National Council of Food and Nutritional Security (Decree 9759/2019). Traditional peoples have been consistently attacked by presidential speeches, which accuse them of blocking development activities and colluding with foreign actors at the expense of national sovereignty (Sauer et al., 2019). Finally, land titling (to landless farmers and indigenous populations) was obstructed. Regarding the indigenous populations, the institutional body responsible for recognizing their lands and receiving their demands was initially transferred to the Ministry of Agriculture, which was blamed for hindering these policies' implementation.

Therefore, the dismantling process has exhibited high visibility in recent years, as politicians wish to pursue a clear and strong tactic. Brazilian far-right partisans are ideologically convinced that dismantling is the most appropriate solution and their electoral base, which is partially composed of conservative groups from the agribusiness sector, showcases a clear preference for dismantling.

\section{Argentina: an intertwined process of dismantling}

The process of the dismantling of policy instruments showed certain ambiguities in the case of Argentina. The Family Farming Law enacted in 2014 during the Cristina Kirchner administration was not modified by the neoliberal orientation of the Macri government which attained power in December 2015. A suspension of land evictions of peasants with precarious access to land was extended to 2019 by the Legislative power. Some programs were also maintained as a means of avoiding increasing conflicts and preserving certain commitments at the international level.

However, and very quickly after the new government reached power, some relevant changes were introduced in the institutionality related to family farming, implying a process of arenashifting with low visibility in terms of mainstream public opinion. The former Secretariat of Family Agriculture (under the Ministry of Agroindustry) was merged with the Secretariat of Coordination and Territorial Development. Other components of the institutional framework were retained, such as a council composed of government officials and representatives of organizations (Consejo de la Agricultura Familiar, Campesina y Indígena), but its internal composition changed, and the number of meetings diminished. By 2018, meetings ultimately ceased and were replaced by decentralized contacts with selected groups. In addition, a specific instance of public-private dialogue concerning agrarian conflicts was abandoned (Nogueira et al., 2017; Montón, 2018).

A different kind of strategy was pursued through the changes instituted in the mechanisms for the implementation of certain policy instruments. For instance, registration in the $\mathrm{Na}-$ tional Registry of Family Farmers (RENAF) enables access to government programs; in 2017, the need for a new registration process was announced. Organizations claimed that they were excluded as registration entities and that new parameters were established, leading to a reduction in the number of registrants (Montón, 2018; Vigil, 2019). In the case of the Monotributo 
Social Agropecuario (MSA), a new form of operation was introduced by the government; again, the consequence was an abrupt reduction in the number of farmers enrolled in the system. MSA was initially conceived as a specific tax system that gives farmers the possibility of issuing invoices and facilitates their access to health services and social security. The government, through the Ministry of Agroindustry, covered part of the individual contribution needed for sanitary insurance payment. In 2018, beneficiaries were required to update their registration within 40 days. Additionally, MSA was transferred to the Ministry of Social Development and Agroindustry ceased its contributions to beneficiaries' insurance. Thus, both instruments were maintained but their effective scope was diminished.

At the same time, other measures could be interpreted as dismantling by arena-shifting. New programs oriented to family farmers and those remaining from previous years were reoriented towards more capitalized segments, assisted on an individual basis (Bertoni and Soverna, 2018; Vigil, 2019). Support for family producers' organizations was reduced or ceased, affecting the smallest ones (Vigil, 2019). In addition, an entrepreneurial view, focused on productive and commercial issues, displaced the emphasis on access to rights that dominated the 20122015 period (Bertoni \& Soverna, 2018; Nogueira et al., 2017).

This bias can also be observed in the requisites for accessing certain instruments. Legislation that began to be promoted during the second mandate of Cristina Kirchner, such as a norm creating a family farming seal, was taken up by the Macri administration. However, the criteria adopted imply strong barriers for small, less capitalized family farmers if there is no public support to facilitate compliance ${ }^{2}$.

Along with these policy measures, other dismantling mechanisms could be subtle, implying a dismantling by default. For instance, the budget allocated to programs was not updated according to inflation (which reached more than 20\% in 2017 and nearly 50\% in 2018). Changes of officials in charge of executive areas at national and provincial levels paralyzed or postponed actions; in some cases, there were complaints about their lack of experience and their designation by partisan policy criteria (Vigil, 2019).

At the same time, a more overt process of active dismantling took place through the drastic reduction in the number of technicians assisting family farmers. Between 2016 and 2018, about 850 workers - nearly $60 \%$ of the total - were fired and some areas were left with virtually no technical assistance (Rang et al., 2018). Organizations denounced the budget reductions to programs oriented to the sector (Montón, 2018). In practice, technicians' field work was minimized, or even paralyzed, affecting subsistence producers to a great extent (Vigil, 2019). The absence of further regulation concerning the Family Farming Law enacted in 2014 facilitated this situation, an issue that will be taken up later.

A proxy of the family farming policies' budget evolution is provided in Figure 3, which includes the programs carried out by the Ministry of Agroindustry financed by external credit and those under the framework of the National Institute of Agricultural Technology (INTA). The figure shows that 2018 saw the most striking cut in funds; however, the ProHuerta program, which is oriented to poverty alleviation in urban and rural areas, was prioritized.

2 - For instance, good production practices and traceability of products must be certified. The application to obtain the seal must specify the production process, who is involved, and the volume produced (Resol. 330/17). 
Figure 3: Argentina. Evolution of funds oriented to family farming

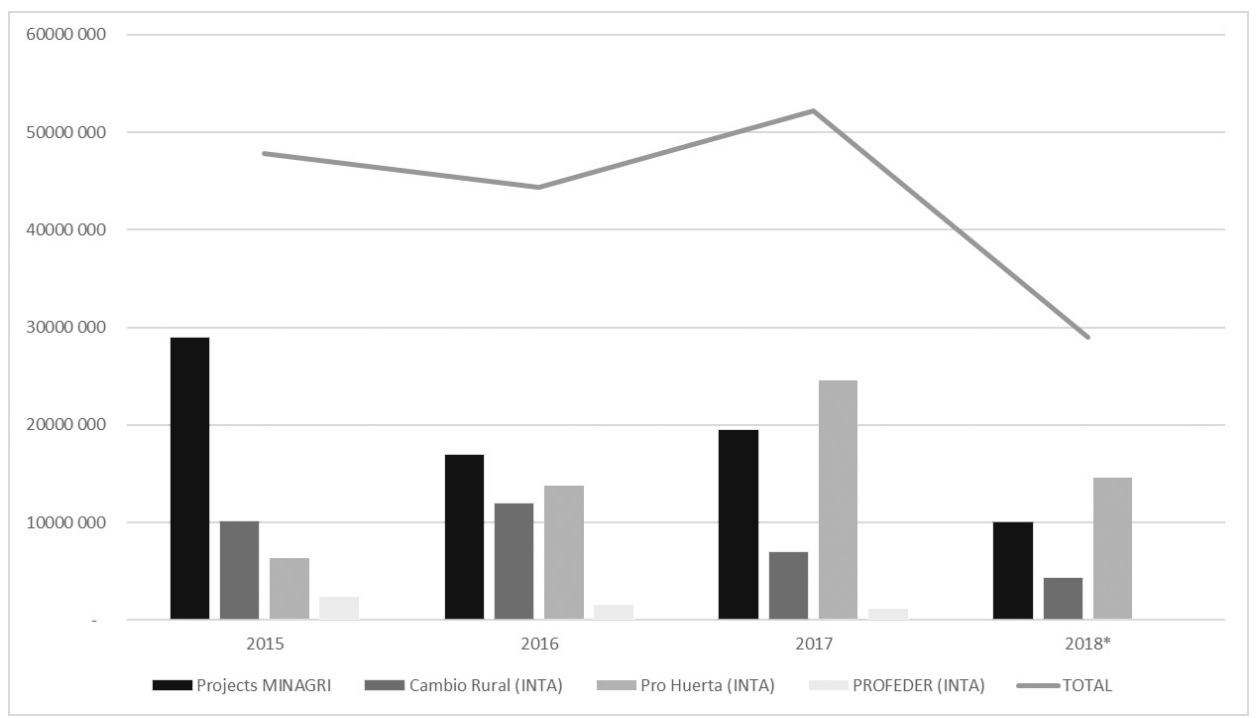

Funds in pesos argentinos were converted to dollars at the exchange rate in the beginning of each year. The budget assigned at the end of each year was considered except for 2018, when the assigned funds were considered.

Source: Authors, based on data provided by DIPROSE (Ministry of Agroindustry) and INTA

Considering the overall process, Nogueira et al. (2017) refer to an emptying of policies related to family farming behind the maintenance of an apparent institutionality. Bertoni and Soverna (2018) speak of a process of de-institutionalization. Beyond this characterization, the regressive evolution of the policy instruments oriented to family farming in Argentina should be evaluated in consideration of the whole picture: taxes on agricultural exports (mainly soybeans) were reduced, the exchange rate was released and a marked devaluation of the Argentine currency took place (of about 400 percent between 10/12/15 and 28/12/18). All these measures benefited export-oriented agribusiness while increasing agricultural input costs for farmers oriented to the domestic market. In addition, the orientation of the Macri administration was clearly expressed through the appointment of a representative of Sociedad Rural Argentina - the organization that represents the nation's big landowners - as Minister of Agroindustry in 2017.

\section{Common stages in the process of policy dismantling}

Drawing on the previous cases, the process of dismantling in Brazil and Argentina can be summarized in three main stages, although these are not always linear or mutually exclusive. First, the maintenance of institutions was followed by changes in policy content, or targeted beneficiaries. In the initial steps, preventing social protests and resistance may be a common strategy. This process is characterized by the preservation of instruments, but also by adjustments in the mandate, position, or name of the responsible institutions. The reduction of funds, human resources and institutional strength is gradual, or even discreet. This is expected, for instance, to preserve economic interests by maintaining farmers as providers or buyers, or even by transferring the benefits that were originally assigned to family farmers to entrepreneurs, according 
to the "arena-shifting" modality. This was the decision made by the Macri administration in Argentina where the institutional framework was gradually downgraded. In Brazil, the Temer administration followed a similar path by first merging the two social and rural development ministries (MDA and MDS).

Second, policy dismantling relied on the severe contraction of both institutions and resources. In Argentina, the most striking features have been the reductions in field technicians, in operational resources to assist family producers and in transferred credits or subsidies. In Brazil, the Temer administration entrusted the management of the family farming and land-reform portfolio to Solidarity, a union competing with the National Confederation of Agricultural Workers (Contag) and the Landless Workers' Movement (MST), the social basis of the former MDA. However, this small union had neither human resources nor social support and so the initiative failed. The alternative was to place the new Secretary of Family Agriculture close to the central power in order to facilitate both political and judicial control of the category. In this context, programs such as Pronaf, which benefited from the interest of some agribusiness groups, was maintained, although with fewer resources, while programs based on alternative approaches (territorial development, support for traditional populations, land reform, indigenous lands) were paralyzed.

The third and final stage of policy dismantling is the suppression of institutionality and the criminalization of rural movements. These strategies rely on the straightforward extinction of family farming policies and on judicial control of reactions to dismantling. This stage corresponds to active dismantling and is currently underway in Brazil, but also in other Latin American countries such as Paraguay and Nicaragua (Freguin-Gresh and Perez, 2018; Friggeri, 2017).

The case studies provide evidence that policy dismantling is more often an incremental process of policy change. Although there are cases of sudden ruptures, a process of sequential stages of growing intensity is more likely to happen. Even in Brazil, where a major political shift and a process of institutional fragilization took place after the 2016 presidential impeachment, dismantling started imperceptibly, initially led by minor institutional changes.

\subsection{Causes of dismantling}

The factors leading to dismantling include structural conditions and contextual and institutional constraints regarding the features of the political system. Brazil and Argentina share several features regarding the macro-level determinants, the politics of the rural sector and the process of development of family farming policy portfolios. A slower pace of economic growth, coupled with a decrease in the dividends coming from agricultural exports, affected state incomes and weakened the ruling coalitions, which were composed of left-wing parties. The subsequent shift in the political orientation of governments - which, in the case of Brazil, has been accompanied by a substantial process of change in the institutional system - was the turning point that affected the dismantling of family farming policies. Finally, support for the family farming category during the 2000s lacked further institutional and political weight in terms of representing a countervailing power to the agribusiness commodities-export sector.

\section{Structural and contextual factors}

Both Brazil and Argentina experienced economic growth during the 2000s, which was partially sustained by the promotion of internal consumption and the export of primary products, particularly to Chinese markets. This economic model was accompanied by a major governmental effort to distribute dividends in order to reduce poverty and social inequality - an effort that 
was maintained after the 2008 financial crisis as growth characterized Brazil and other countries in the global South, while economies of the global North faced recession. Nevertheless, the distribution of income and wealth remained uneven, especially in rural areas, and these countries' economies remained unstable in the international markets (Milhorance, 2018; Sabourin et al., 2015).

Furthermore, a few years after the global financial and economic crisis, the effects of recession also hit commodities export-oriented countries such as Brazil and Argentina. This initially resulted in budget cuts at the national level, which were applied in particular to policies linked to minority groups such as indigenous peoples, peasants' groups and landless farmers. Other Latin American countries followed a similar path, namely Bolivia, Uruguay, Costa Rica and Nicaragua (Sabourin and Grisa, 2018). Some scholars believe that, in the early 2010s, Brazil, Argentina and other emerging countries closed the expansion cycle that was initiated in the 2000s (Salama, 2014).

Along with the economic crisis, these countries faced political instability and governmental shifts. In Brazil, these factors led to the impeachment of the Workers' Party president, Dilma Rousseff, in 2016. The progressive left-wing government was replaced by conservative and ultraliberal political groups, reaching a higher degree of radicalization after the election of the far-right candidate, Jair Bolsonaro, in 2018. In Argentina, the progressive character of the Kirchner administrations, which ruled the country between 2003 and 2015, was replaced by the neoliberal administration of Mauricio Macri who promoted several austerity policies. These governmental shifts reinforced economic and political groups opposed to the development of family farming, which created an increasingly conflictive, or de-legitimizing, environment and led to the reduction of public investment in the sector. This process contributed to the dismantling of the family farming policy portfolio that was beginning not only in Brazil and Argentina, but also in other Latin American countries (Grisa et al., 2018; Vergara-Camus and Kay, 2017).

The external drivers of this dismantling process include the global wave currently contesting social democratic models and multilateralism (Levitsky \& Ziblatt, 2018), which has reached Latin America and particularly Brazil. This wave paved the way to challenging the basis of social democracy, as well as the principles inherent in family farming policies, such as social participation in public policies, productive inclusion and protection of minority groups. In parallel, there has been a fragmentation of traditional social movements in Latin America, particularly trade unions, national federations and grassroots movements (Fachin, 2010).

In some countries, the co-opting of popular leaders to assume responsibilities in left-wing governments affected their leadership, or weakened their vigilance, and consequently reinforced the sector's political fragmentation. In Brazil, a distinction can be made between the so-called "new social movements" (environmentalists, indigenous groups and agroecologists) (Touraine, 1978) on the one side, which are less aligned with governmental efforts, and traditional unions on the other side (Gohn, 2011). The former have managed to mobilize broader sectors in society; however, they have more recently faced attacks, including criminalization by the judiciary power (Sauer \& Mézsáros, 2017). In Argentina, together with the constitution and the legal formalization of the Federation of Family Farming Organizations (Fonaf) in 2011, other alternative initiatives led by landless producers, peasants and members of indigenous communities have emerged which questioned the "close ties" between Fonaf and the national government (Nogueira et al., 2017).

Nevertheless, the final, decisive structural factor in the dismantling process is the lack of rupture with the dominant economic model that drove the main agricultural policy strategies. 
Even during progressive administrations, the support of governments and banks that was given to the agribusiness commodities-export sector remained untouched. Both in Brazil and Argentina, income redistribution to family and peasant farmers, as well as to other traditional peoples and communities, was marginal, sometimes corporatist, and related to specific social bases (Sabourin, 2018; Vergara-Camus and Kay 2017). In general terms, the governments' initial goal was to use the positive trade balance of commodity exports to finance social compensatory or pro-family farming policies. This was feasible during the early 2000s, given the high prices of agricultural commodities and the tacit agreement between states and the agribusiness sector; but it was a compromise that ultimately changed after the economic crisis.

As stated by Bauer et al. (2012), if there is little opposition, dismantling can be pursued to attack the core of a policy directly. Power relations changed in the mid-2010s and governmental support for family farming groups was no longer a priority. As discussed, the dismantling process was gradual, beginning with discreet budget cuts, justified by the economic crisis, until reaching an active and open political strategy. Therefore, depending on the power relations between beneficiaries, or between sectors, as well as on the capacity of government or affiliated media to sway public opinion, dismantling may not be "inherently unpopular" or "extremely treacherous" (Pierson, 1994).

\section{Institutional constraints and opportunities}

In addition to the structural factors, the weight of the institutional constraints confronting policymakers should be considered. These include not only those aspects related to the political system's features, but also the perception of costs and benefits, which varies according to the types of policies being considered. The greater the number and power of veto players, the lower the probability that an active dismantling strategy will be used, or that it will succeed (Bauer et al., 2012). For instance, Bauer et al. refer to the features of the US polity - namely legalism, distributed power and many checks and balances - that constrain dismantling and prevent "unilateral strategies." Indeed, the more that politicians need to seek consent from institutional, party, or other societal actors, the more costly the process becomes. Therefore, the institutional - even constitutional - context influences not only the mode, but also the concrete target, of policy dismantling (Bauer et al., 2012).

Overall, both Brazil and Argentina have faced institutional drawbacks, along with political and economic crisis. A detailed analysis of the governmental shifts in these countries is beyond the scope of this article. Nevertheless, it is worth highlighting some of their trends: the fragilization of the progressive governments in place; the active role of media groups largely represented by conservative actors; the denunciations of left-wing leaders' corruption (Fuser, 2018). In Brazil, the process of dismantling went through a deeper process as it resulted from the fragilization of its political institutions. There has been a growing tension between the fragmented political system, which is characterized by a multi-party coalition presidentialism (presidencialismo de coalizão), and the legal system which has progressively acquired the prerogative of regulating political debate. All this has led to the politicization of legal institutions and the judicialization of national politics (Vilhena, 2018).

Neither public opinion, nor the perception of the distribution of the costs and benefits of dismantling, are objective; they are significantly affected by the institutional structures that obtain a certain momentum in a political system. Moreover, as Bauer et al. (2012) discuss, the features of each policy matter. According to the authors, the costs to be imposed on vulnerable (and deserving) beneficiaries when dismantling social policies may be concentrated, while the benefits are diffused across the rest of society. This particular feature would exert a powerful 
and constraining influence on the way in which such policies are dismantled. In other words, the dismantling of this kind of policy would commonly start by way of more discreet paths.

Nevertheless, the preferences of the potentially affected political actors differ and the perception of the costs and benefits varies greatly depending on the historical meaning that a certain group of policies acquires. In Latin America in general, and particularly in Brazil, family farming policies were built largely thanks to the active role of social rural movements and their ability to form coalitions with governmental actors in specific periods. These policies were built on social struggles and on the institutionalization of a dual system that promoted concurrently distinct (and sometimes divergent) rural-development models (Milhorance, 2018). This led to tensions and contradictions between different state agencies, which remained unresolved and ultimately left space for the dismantling of actions when new administrations reached power.

An additional institutional factor observed in Brazil is the Bolsonaro administration's inclination to govern using presidential decrees. This leaves the congress and the constitutional court with the decision of whether to accept or refuse some of the daily policy options and reinforces the gradual judicialization process mentioned above (Vilhena, 2018). The role of Brazil's Constitution in protecting basic social rights was also questioned when congress approved a constitutional amendment that created a new fiscal regime for reducing health and education spending (95/2016). In the same way, although the right to adequate food was approved as constitutional in 2010 (amendment 64/2010), there is no consensus in Brazil regarding the relation of this right to family farming policies.

Apart from the features of each political system, the specific institutionality in the design of family farming policy portfolios may influence their resilience; in other words, it may affect their ability to resist opposition over the medium-to-long term. In Brazil, this institutionality relied on the federal government (ministerial guidelines), which is also the main source of funds used to implement them. Rousseff's impeachment in 2016 weakened these institutions at the national level. The lack of sufficiently powerful veto players in subnational institutions and in the (predominantly conservative) congress reduces prospects for constraining their dismantling. In Argentina, despite the increase in funds devoted to family farming policies during the 2000s, there was a frequent reliance on international subsidies or loans (Sabourin et al., 2015; Grisa et al., 2018). In this country, a family farming law was enacted in 2014 (Law $27.118 / 2014)$, but it did not include an allocation of specific funds to the sector; to be in effective operation, a law must be accompanied by a legal measure that establishes the way by which the recognized rights are exercised.

If the dismantling process began with the reduction of funds in the context of economic crisis, it was later shaped by voluntary, intentional dismantling as a portion of the political groups that took office actually perceived family farming policies not only to be ineffective but also to be on the opposite side of their preferences. The cost of such a process is perceived as limited as a common issue in Latin America is the lack of political weight of family farmers in terms of organizations and alliances among/with the broader society when facing agribusiness-sector resources and power (Sabourin, Sotomayor and Samper, 2015).

Therefore, the case of family farming policies in Argentina and Brazil aligns with Bauer et al.'s findings regarding the weight of political and structural factors in policy dismantling, particularly in political systems marked by institutional fragilities and by veto players who are limited in number (and in power). However, the results differ from the authors' theoretical expectations regarding the "type" of policies. Evidence in Brazil and Argentina shows that perception 
of the costs and benefits of dismantling varies across jurisdictions - and not only across policy "types" or "sectors". This relates to the features of the political systems and to the socio-historical meaning of each policy portfolio in this system, their recognition in public opinion and in dominant coalitions. Finally, the relevance of institutional constraints may also be discussed within the broader context of the increasing fragilization of democratic institutions. As stated by several constitutionalists, the system of checks and balances is key; however, this system is not sufficient to prevent attacks against democratic institutions, as their resilience also relies on "informal" norms or, in other words, on both society's and politicians' commitment to these institutions (Levitsky \& Ziblatt, 2018; Vilhena, 2018). In this context, the mobilization of social movements and their impact on national and international public opinion are the remaining options for resistance.

\section{Perspectives and a future research agenda: reactions and resistance}

The framework developed by Bauer et al. (2012) comprised the discussion of the outputs in terms of policy retraction (density and intensity) resulting from policy dismantling. Yet studies regarding not only the outcomes of this process, but also the reactions to it, are still underdeveloped. Although this issue needs a specific study, some general trends and points for defining a future research agenda are sketched out below.

It is important to highlight that reactions have not been homogeneous, given the diversity of resistance movements at the national level and the existence of distinct loci of social, land and socio-environmental conflicts. Despite this heterogeneity, three main trends were observed and these deserve further theorization and empirical analysis:

- Bureaucratic adaptation: in some cases, there is a relatively passive adaptation of civil servants and staff involved in the implementation of policies being dismantled. This also applies to the portion of social movements and trade unions supposedly interested in the maintenance of certain policies. This was the case with Contag, the main representative of family farming in Brazil, which preferred to negotiate with the Temer Government in order to maintain the specific credit allowance allotted to family farming.

- Active and passive social resistance: Active resistance may take several forms, ranging from conflicts in the countryside to long-term mobilization processes. The major campaigns are commonly organized by groups historically involved in social struggles (such as the landless, traditional communities and peasant movements) and comprise the protection of basic rights. This kind of resistance may involve strategies to gain public visibility and the forging of alliances with urban actors. In Argentina, several entities have gathered to promote joint actions; organizations such as the Union of Land Workers (UTT) carried out several "verdurazos" in main cities (the selling of groceries at very affordable prices) as a form of protest. In Brazil, large free meals prepared with agroecological products ("banquetaços") were organized in public spaces in 2019 as a means of attracting attention to the extinction of the National Council on Food Security. Maintaining political interaction is an additional passive-resistance strategy. In Brazil, despite the extinction of the territorial citizenship program, several councils continue to meet and discuss policy decisions informally at the state or municipal level, or with the support of the Federated States, as in the Northeast region (Milhorance, Sabourin and Mendes, 2019).

- Label change by international/national organizations: Relabeling family farming projects as a means of addressing global challenges is an additional reaction to policy dismantling. No longer able to fund family farming projects in collaboration with con- 
servative or neoliberal governments, international cooperation agencies, such as IFAD, IICA and UNDP, began to raise funds for "climate-change adaptation," support of "lowincome rural populations," promotion of "regional development" and "technological innovation" as a pretext for maintaining their technical and financial support to this group. For instance, FIDA-Mercosur, anticipating the crisis, decided to transfer an institutional strengthening and training project for the Confederation of Family Producers' Organizations of the Mercosur countries to its Rome-based office.

Working in the same direction, but at a national level, civil servants committed to family farming have tried to develop solutions to circumvent internal opposition, such as employing resources assigned to technological projects to support broader objectives related to family farming and to maintaining their presence at the territorial level.

Another type of resistance came from the Latin American regional-integration bodies, Union of South American Nations (UNASUR), Southern Common Market (MERCOSUR) and, more particularly, the Community of States of Latin America and the Caribbean (CELAC), which established a Ministerial Meeting on Family Agriculture and Rural Development. The latter reinforced its commitment to support the Plan of Action for Family Agriculture in El Salvador in December 2017 (Declaración Ministerial de la CELAC sobre Agricultura Familiar, 2017).

\section{Conclusion}

Family farming policies developed significantly in Latin America between 1995 and 2015, often promoted by rural social movements. Despite their results in terms of the promotion of food and nutritional security and productive and social inclusion, a process of dismantling has recently taken place. This paper has analyzed the causes and mechanisms of this process and provided elements to answer the question of why these relatively new and socially oriented policies have been so quickly and smoothly dismantled. Several structural, contextual and institutional factors were presented.

First, the article discussed the lack of rupture within the dominant agricultural policy model which is based on the allocation of resources primarily to the commodity export-oriented agribusiness. Family farming policies benefited from an increase in political legitimacy and funds during the 2000s and early 2010s; however, this was possible only as far as they were able to reduce social upheaval, or did not compete with the interests of national agrarian capitalism (Sabourin, 2018). Once opposing coalitions took office in both Brazil and Argentina, these policies lost importance in government and in parliament. Other factors included the global financial and economic crises, which contributed to the deepening of political instability in Brazil and Argentina. It is worth highlighting that, in both countries, the dismantling process occurred in a context of political changes that, in the case of Brazil, were also linked to the extranational interests of international financial capitalism, particularly land-grabbing (Sauer et al., 2019). Finally, the dismantling of family farming policies — and other policies as well - goes hand-in-hand with the global wave of fragilization of democratic institutions and the arrival in power of right-wing conservative groups.

Although the structural and contextual factors are more relevant in explaining the causes of the dismantling process, its speed and degree were related in particular to institutional fragilities in policy design and to the limited number (and power) of veto players in both countries. Therefore, although dismantling first began with discreet strategies such as default dismantling, particularly justified by budget cuts and the economic crisis, they quickly acquired visible and active features. Lastly, the results of this study differ in certain terms from Bauer et al.'s 
framework as the perception of the costs and benefits of dismantling varies according to the socio-historical and political meaning of each group of policies.

The results call for a more detailed analytical framework of the causes, modalities and stages of policy dismantling to facilitate future in-depth and regionally based analyses. The notion of resilience in the design of policy portfolios may also add to this literature and deserves further research. Moreover, combining the theoretical framework with traditional policy-change theories (institutionalism, internationalization), democracy-regression theories and resistance strategies (reshaping, bypassing and overt and passive resistance) seems promising.

In terms of policy proposals, this study shows that it is strategic to overcome the corporatism of certain unions, to expand and strengthen coalitions of family farming with urban movements, such as environmentalists or those promoting ecology, food and nutrition security, education and health, and - in particular - to develop alliances with consumers willing to support family production of quality and healthy food. These kinds of policies can be considered reformist in the sense that they aim to improve current situations without fundamentally altering existing structures (Vergara \& Kay, 2017). Nonetheless, in the present scenario, they seem important for supporting strategic actors in the rural sector and sustaining their connections with other sectors.

\section{Bibliography}

Adib, A., \& Almada, F. (Eds.) (2017). Políticas públicas y marcos institucionales para la agricultura familiar en América Latina. Instituto Interamericano de Cooperación para la Agricultura. Chile: IICA.

Alves, E., \& Rocha, D. (2010). Ganhar tempo é possível. In J. G. Gasques, J. E. R. Vieira Filho, \& Z. Navarro (Eds.), A Agricultura Brasileira: Desempenho, desafios e perspectivas (pp. 275-290). Brasília: IPEA, Instituto de Pesquisa Econômica Aplicada.

Aquino, J. R. de, \& Schneider, S. (2010). 12 anos da política de crédito do PRONAF no Brasil (19962008): Uma reflexão crítica. In: VIII Congresso Latinoamericano de Sociologia Rural, 2010, Porto de Galinhas, Anais do Congresso Latino Americano de Sociologia Rural. Porto de Galinhas (PE): ALASRU.

Bauer, M. W., \& Knill, C. (2012). Understanding Policy Dismantling: An Analytical Framework. In M. W. Bauer, A. Jordan, C. Green-Pedersen, \& A. Héritier (Eds.), Dismantling Public Policy (pp. 3051). Oxford: Oxford University Press.

https://doi.org/10.1093/acprof:oso/9780199656646.003.0002

Bauer, M. W., Green-Pedersen, C., Héritier, A., \& Jordan, A. (2012). Dismantling Public Policy: Preferences, Strategies, and Effects. Oxford: Oxford University Press.

Bertoni, L., \& Soverna, S. (2018, November). Evolución de la Asistencia Técnica y la Extensión Rural en la Secretaría de Agricultura Familiar, Coordinación y Desarrollo Territorial del Ministerio de Agroindustria de la Argentina (MINAGRO). Presented at the X Congreso de la Asociación Latinoamericana de Sociología Rural (ALASRU), Montevideo, Uruguay.

Craviotti, C. (2014). La agricultura familiar en Argentina: Nuevos desarrollos institucionales, viejas tendencias estructurales. In C. Craviotti, Agricultura Familiar En Latinoamérica: Continuidades, Transformaciones y Controversias (pp. 175-204). Buenos Aires: Ciccus.

Ezzine de Blas D., Le Coq J.F. \&Guevara Sanginés, A. (Eds.). (2017). Pagos por servicios ambientales en América Latina: gobernanza, impactos y perspectivas. Universidad Ibero Americana \& Red Política Pública $y$ desarrollo rural en América latina (PPAL). México: Edición Iberoamericana. 
Fachin, P. (2010, April). Os desafios dos movimentos sociais hoje. Revista do Instituto Humanitas Unisinos, (325). Retrieved from http://www.ihuonline.unisinos.br/index.php

Freguin-Gresh, S., \& Perez, F. J. (2018). Agricultura familiar y capitalismo agrario en las políticas públicas de Nicaragua: Entre dualidad y compromisos. Raízes: Revista de Ciências Sociais e Econômicas, 38(1), 65-79.

Friggeri, F. P. (2017). Paraguay después del Golpe: El precio de ponerse colorado. Foro Internacional, 57(1), 188-226.

Fuser, I. (2018). Conquistas e fracassos dos governos progressistas: elementos para o balanço de um ciclo político que se recusa a morrer. Revista de La Red Intercátedras de Historia de América Latina Contemporânea: Segunda Época, (8), 67-76.

Gohn, M. da G. (2011). Movimentos sociais na contemporaneidade]. Revista Brasileira de Educação, 16(47), 333-361.

González, F., \& Manzanal, M. (2010). Agricultura Familiar y Soberanía Alimentaria. Una necesaria articulación en el ámbito del MERCOSUR, desde la perspectiva del caso argentino. In: VIII Congresso Latinoamericano de Sociologia Rural América Latina: Realineamientos Políticos y Proyectos En Disputa, 15, 2010, Porto de Galinhas, Anais do Congresso Latino Americano de Sociologia Rural. Porto de Galinhas (PE): ALASRU

Grisa C., Sabourin E. (2019). Agricultura Familiar: de los conceptos a las políticas públicas en América Latina y el Caribe. In 2030 - Alimentación, agricultura y desarrollo rural en América Latina y el Caribe, No.15. Santiago de Chile: FAO. Retrieved from http://www.fao.org/3/ca5087es/ca5087es.pdf

Grisa, C., Sabourin, E., \& Le Coq, J-F. (2018). As políticas públicas para a agricultura familiar na América Latina e Caribe: Um balanço para a construção de uma agenda de pesquisa. Raízes: Revista de Ciências Sociais e Econômicas, 38(1), 7-21.

Gürtler, K., Postpischil, R., \& Quitzow, R. (2019). The dismantling of renewable energy policies: The cases of Spain and the Czech Republic. Energy Policy, 133, 110881.

https://doi.org/10.1016/j.enpol.2019.110881

Hentz, C., \& Hespanhol, R. A. de M. (2017). Políticas públicas de desenvolvimento rural: uma análise do Programa de Aquisição de Alimentos (PAA) nos municípios de Cunha Porã e Saltinho/SC. Revista Campo - Território: Revista de Geografia Agraria, 12 (27), 29-58

https://doi.org/10.14393/rct122702

Howlett, M. (2019). Procedural Policy Tools and the Temporal Dimensions of Policy Design. Resilience, Robustness and the Sequencing of Policy Mixes. International Review of Public Policy, 1(1:1), 27-45.

Howlett, M., \& del Rio, P. (2015). The parameters of policy portfolios: Verticality and horizontality in design spaces and their consequences for policy mix formulation. Environment and Planning C: Government and Policy, 33(5), 1233-1245.

https://doi.org/10.1177/0263774X15610059

Jordan, A., Bauer, M. W., \& Green-Pedersen, C. (2013). Policy Dismantling. Journal of European Public Policy, 20(5), 795-805.

https://doi.org/10.1080/13501763.2013.771092

Levitsky, S., \& Ziblatt, D. (2018). Como as democracias morrem. Rio de Janeiro: Zahar.

Mahoney, J. (2001). Path-Dependent Explanations of Regime Change: Central America in Comparative Perspective, Studies in Comparative International Development, 36 (1), 111-141. https://doi.org/10.1007/BF02687587 
Mattei, L. (2018). Les conséquences socio-économiques du coup d’État parlementaire au Brésil. Brésil (s). Sciences Humaines et Sociales, (1), 1-13.

https://doi.org/10.4000/bresils.2890

Milhorance, C; Sabourin E., Mendes P. (2019) Adaptation to climate change and policy interactions in Brazil's semiarid region, ICPP 4 Conference, Montreal, June 2019.

Retrieved from http://www.ippapublicpolicy.org//file/paper/5cfabaadde100.pdf

Milhorance, C. (2018). New Geographies of Global Policy-Making: South-South Networks and Rural Development Strategies (1st ed.). New York and London: Routledge.

Monton, D. (2018). Argentina: La Agricultura Familiar, entre el vaciamiento y la disputa campesina por la tierra. Biodiversidad en América Latina. Retrieved from http://www.biodiversidadla.org/Documentos/Argentina_La_Agricultura_Familiar_entre_el_vaciamiento_y_la_disputa_campesina_ por_la_tierra

Navarro, Z. \& Pedroso, M.T.M. (2011). Agricultura familiar: é preciso mudar para avançar. Brasília (DF): Embrapa Informação Tecnológica.

Niederle, P., Grisa, C., Picolotto, E. L., \& Soldera, D. (2019). Narrative Disputes over Family-Farming Public Policies in Brazil: Conservative Attacks and Restricted Countermovements. Latin American Research Review, 54(3), 707-720.

http://doi.org/10.25222/larr.366

Nogueira, M. E., Urcola, M. A., \& Lattuada, M. (2017). La gestión estatal del desarrollo rural y la agricultura familiar en Argentina: Estilos de gestión y análisis de coyuntura 2004-2014 y 2015-2017. Revista Latinoamericana de Estudios Rurales, 2(4).

Pierson, P. (1994). Dismantling the welfare state? Reagan, Thatcher and the politics of retrenchment. Cambridge: Cambridge University Press.

Rang, C., Romero, M., Maloberti, K.\& Rodríguez, P. (2018). Roundtable: Debilitamiento de las instituciones del sector público agropecuario. Cátedra Libre de Estudios Agrarios Ing. Horacio Giberti, Buenos Aires, IADE, 31 October 2018.

Ribeiro, V. V. (2017). Terra e liberdade: Comparando experiências de reforma e contrarreforma agrária no Peru e no Chile (1962-1997). Passagens: Revista Internacional de História Política e Cultura Jurídica, 9(2), 266-285.

Rosanvallon, P. (2014). La contre-démocratie. La politique à l'âge de la défiance. Paris: Le Seuil.

Sabourin, E. (2018). Analyse socio-historique de la politique d'agriculture familiale au Brésil. Brésil(s). Sciences humaines et sociales, (13).

https://doi.org/10.4000/bresils.2439

Sabourin E., Grisa C.\& Lopes Filho M. (2018). Regional diffusion of Brazilian public policies for the strengthening of family farming in Latin America and the Caribbean, International Conference on Policy Diffusion and Cooperation, São Paulo, UNIFESP may 2018.

Sabourin E., Le Coq J.-F., Fréguin-Gresh S., Marzin J., Bonin M., Patrouilleau M. M., Vázquez L.\& Niederle P. (2018). Publicpolicies to supportagroecologyin LatinAmerica and the Caribbean. Perspective, 45. https://doi.org/10.19182/agritrop/00020

Sabourin E. \& Grisa C. (Eds.) (2018). A difusão de políticas brasileira para agricultura familiar na América Latina e Caribe. Porto Alegre: Ed. Escritos.

Sabourin, E., Grisa C., Lopez Filho, M.; et alli (2020). Regional diffusion of Brazilian social and rural public policies in Latin America and the Caribbean. In O.P Oliveira, C. Osorio Gonnet \& C. K da S. Leite (Eds.), Latin America and Policy Diffusion: From Import and Export (1st ed.) (pp. 101-127), London: Routledge. 
Sabourin, E., Samper, M., \& Sotomayor, O. (Eds.). (2015). Políticas públicas y agriculturas familiares en América Latina y el Caribe: Nuevas perspectivas. San José: IICA.

Sabourin, E., Patrouilleau, M. M., Le Coq, J.-F., Freguin-Gresh, S., Vázquez, L., \& Niederle, P. (Eds.). (2017). Políticas Públicas a favor de la agroecología en América Latina y el Caribe. Porto Alegre: Evangraf / Criação Humana, Red PP-AL/ FAO.

Salama, P. (2014). Des pays toujours émergents? Paris : La Documentation française : DILA - Direction de l'information légale et administrative.

Sauer, S., \& Mézsáros, G. (2017). The Political Economy of land struggle in Brazil under Workers' Party Governments. Journal of Agrarian Change, 17, 397-413.

https://doi.org/10.1111/joac.12206

Sauer, S. Leite, A.;Oliveira, K. \& Shankland, A. (2019).The Implications of Closing Civic Space for Sustainable Development in Brazil. Mimeo, IDS and ACT Alliance. Retrieved from https://opendocs.ids.ac.uk/opendocs/handle/20.500.12413/14507

Simeon, R. (1976). Studying public policy. Canadian Journal of Political Science/Revue Canadienne de Science Politique, 9(4), 548-580.

Touraine. A. (1978). La Voix et le Regard Sociologie des mouvements sociaux. Paris: Le Seuil.

Vergara-Camus L.\& Kay, C. (2017). Agribusiness, peasants, left-wing governments, and the state in Latin America: An overview and theoretical reflections. Journal of Agrarian Change, vol. 17 (2): 237-437.

Vigil, C. (2019). Agricultura familiar campesina e indígena en la Argentina, 2004-2017. Montevideo: Dep. De Publicaciones CLAEH.

Vilhena, O. V. (2018). A batalha dos poderes: Da transição democrática ao mal-estar constitucional. São Paulo-SP: Companhia das Letras. 